Magdalena Bogustawska

\title{
Powrót do Čivutany. Otwarcie Centrum Pamięci o Zagładzie Żydów z Macedonii
}

Čivutana to niewielka, malownicza dzielnica Skopja, a zarazem jedno z wielu osiedli Sefardyjczyków na Półwyspie Bałkańskim, powstałych po wypędzeniu ich przez króla Ferdynanda z Hiszpanii pod koniec XV w. ${ }^{1}$ Ponieważ osiedlanie się żydowskich przybyszy $\mathrm{w}$ miastach imperium osmańskiego, $\mathrm{w}$ tym również w Sołuniu (nazwanym z uwagi na dużą liczebność i aktywność dispory „bałkańską Jerozolimą"), Sarajewie, Bitoli i Skopju, miało charakter grupowy, zdołali oni zachować w nowym środowisku podstawowe cechy etniczne i specyfikę kulturową (język, ubiór, zwyczaje). Jednocześnie w czasie długotrwałego panowania tureckiego osadzona w miastach kultura bałkańskich Sefardyjczyków podlegała silnej orientalizacji, a także - choć zdecydowanie w dużo mniejszym stopniu - slawizacji.

W początkach XX w. położona nad Vardarem Čivutana była uznawana za starą etniczną kolonię. Dawni przemierzający Bałkany podróżnicy, którzy w swych relacjach wspominali o Macedonii, traktowali miejscowych Żydów jako jedną z najstarszych grup osiedleńczych, przybyłych do Skopja spoza Bałkanów. Tworzyli oni zwartą wspólnotę, choć byli obecni nie tylko w tej dzielnicy, lecz także zmieszkiwali w rozproszeniu inne części miasta. W „żydowskim maalu” ${ }^{2}$ znajdowały się prywatne domy, zakłady rzemieślnicze, sklepy i kramy, gdyż i na Bałkanach Żydzi stanowili (obok Greków, Cincarów (Arumunów), Turków) główną część ludności zajmującej się handlem. W centrum dzielnicy żydowskiej, u stóp wzgórza, na którym wznosi się pamiętająca Rzymian twierdza, od czasów tureckich zwana „Kale”, znajdowała się synagoga znana jako Kaal Hadaš lub Midroš Kadaš. W okresie międzywojennym, kiedy miasto po latach rządów osmańskich weszło w skład Królestwa Jugosławii i zaczęło się rozwijać na wzór europejski, pojawiły się w Čivutanie kawiarnie z ogródkami, a także wybudowano szkołę; tu przyjmowali pacjentów

${ }^{1}$ Turcy mianem čivutana określali po prostu żydowską dzielnicę (na przykład także w Nišu), z czasem utrwaliło się ono w funkcji nazwy własnej.

${ }^{2}$ Maalo - kwartał; przejęte z języka tureckiego określenie dzielnicy - części miasta lub osady wiejskiej. 
wzięci żydowscy lekarze. Nieopodal linii kolejowej i znajdującego się w jej pobliżu cmentarza katolickiego usytuowany był kirkut.

Ta „wyobrażona” topografia kwartału, którego od dawna już nie ma, istniejąca dziś tylko we wspomnieniach i opisach historycznych, na rycinach i fotografiach, przez długi czas była dla mieszkańców Macedonii jednym z nielicznych świadectw żydowskiej obecności w mieście. Warto nadmienić, że w formującym się zasadniczo w XX w. macedońskim dyskursie historycznym temat żydowski jest właściwie nieobecny. Emancypująca się społeczność koncentrowała wysiłki na wykazaniu swej macedońskości, udowodnieniu jej substancjalności i odrębności, a zatem wszelkie wpływy uznane za „obce”, wszystkie elementy identyfikowane z innymi etnosami były w zależności od przydatności propagandowej bądź włączane w dyskurs narodowy (starożytność, a zwłaszcza osoba Aleksandra Wielkiego), bądź też odrzucane, marginalizowane lub przemilczane, gdyż zdawały się zagrażać tezom o oryginalności i ciągłości kultury macedońskiej. Współcześnie, gdy dążenia Macedończyków do samostanowienia zostały uwieńczone ustanowieniem w $1991 \mathrm{r}$. niezależnego państwa, motywacji do zainteresowania grupami tworzącymi na tym terytorium zarówno niegdyś, jak i dziś „mozaikę narodów, religii, kultur”, dostarcza polityka pokojowej koegzystencji grup etnicznych i wyznaniowych. Jej zasady zostały sformułowane w odpowiedzi na okupiony wojną rozpad Jugosławii oraz albańsko-macedoński konflikt zbrojny z 2001 r. Propagowana przez władze i instutucje międzynarodowe koncepcja zakłada istnienie polinarodowego państwa, w którym wielokulturowość staje się naczelną wartością, a różnica - synonimem historycznego i cywilizacyjnego bogactwa. W ten projekt nowoczesnego państwa doskonale wpisuje się zatem idea odzyskania dla pamięci zbiorowej tradycji i losów macedońskich Żydów.

Materialnym symbolem przypominającym o istnieniu skopijskiej Čivutany i życiu jej mieszkańców stało się otwarte 10 marca 2011 r. Centrum Pamięci o Zagładzie Żydów z Macedonii (Memorijalen centar na Holokaustot na Evreite od Makedonija), usytuowane przez architektów i urbanistów właśnie w miejscu niegdysiejszej zabudowy żydowskiej, w historycznym centrum miasta, w pobliżu čaršiji - urokliwej, chętnie odwiedzanej przez turystów „tureckiej starówki”. Budowa ośrodka była możliwa dzięki podjętej w 2003 r. przez parlament Republiki Macedonii uchwale o denacjonalizacji mienia pożydowskiego i przekazaniu go Wspólnocie Żydowskiej, której siedziba znajduje się w Skopju.

Temat Zagłady stanowi ramę muzealnej opowieści, zaprezentowanej zwiedzającym z okazji inauguracji działalności Centrum. Owa tematyczna klamra ma swój przestrzenny odpowiednik w postaci ustrukturyzowania wystawy. W sali znajdującej się na parterze przy wejściu do budynku umieszczono wagon kolejowy, a w korytarzu instalację (przypominającą kształtem las lub płomienie) skonstruowaną z fotografii pomordowanych. Środkowa, usytuowana na pierwszym piętrze ekpozycja dotyczy bałkańskiej historii Sefardyjczyków, którzy wygnani z Hiszpanii, podążyli wzdłuż szlaków handlowych południowej Europy ku miastom imperium otomańskiego, takim jak: Sarajewo, Belgrad, Niš, Skopje, Saloniki 
(w niektórych już mieszkali zadomowieni wcześniej Żydzi). Turcy bowiem zapewniali przedstawicielom innych niż islam religii pewną wyznaniową i kulturową autonomię, choć oczywiście traktowali ich jak obywateli drugiej kategorii. Ten dział wystawy (mający charakter tymczasowy i przenośny), bogato ilustrowany reprodukcjami starych fotogramów, ukazuje diasporę w skali Półwyspu Bałkańskiego, a tym samym nadaje całości wymiar regionalny, ukazuje ponadlokalny charakter wspólnoty żydowskiej, skonsolidowanej wokół tradycji sefardyjskiej, języka ladino i „nowego” miejsca zamieszkania (państwa osmańskiego), a także dowodzi ogromnej wartości i znaczenia dorobku cywilizacyjnego i duchowego społeczności uczestniczącej w dziejach Bałkanów od przeszło 500 lat. Ostatnia, zamykająca ekspozycję część dotyczy tragicznych doświadczeń, które stały się udziałem Żydów pochodzących z miast Macedonii (tu w sensie geograficznym) w okresie drugiej wojny światowej.

„Szukam cię, a ciebie nie ma,/W karczmie, na stacji...”. Ten fragment sefardyjskiej pieśni miłosnej, wypisany wśród wielu innych cytatów ozdobną czcionką na jednej z muzealnych tablic prezentujących stare fotografie bałkańskich Sefardyjczyków (najpierw w orientalnych, potem coraz częściej europejskich strojach), odzwierciedla nostalgiczny ton ekspozycji. Ta dawna pieśń ludowa nabiera dodatkowych, symbolicznych znaczeń, gdy - zapewne zgodnie z intencją organizatorów Centrum - odniesiona zostanie do wydarzeń z 1943 r. i ich konsekwencji, czyli niemalże całkowitego zniszczenia populacji żydowskiej na obszarze Macedonii.

Osią wystawy jest osobliwe tableau otwierające część poświęconą wojennym i powojennym losom macedońskich Żydów i niejako powtórzone we wspomnianej instalacji przy wejściu do ośrodka. Otóż jeszcze w 1942 r. władze bułgarskie na przyłączonych do Bułgarii terenach Macedonii, Tracji Zachodniej i częściowo Grecji zarządziły na mocy umowy koalicyjnej z Niemcami rejestrację wszystkich dorosłych osób z rodzin żydowskich z obszarów okupowanych. Każdy dorosły członek wspólnoty żydowskiej musiał złożyć w odpowiednim urzędzie opatrzoną zdjęciem informację o sobie, zawierającą: imię i nazwisko, adres zamieszkania (spisowi nie podlegały dzieci). Ta skrupulatnie sporządzona ewidencja stała się później wyjątkowym, być może jedynym tego rodzaju dokumentem - dossier zagłady Żydów z Macedonii - a po wojnie na jego podstawie ustalono tożsamość zamordowanych. Żydzi z miast Macedonii Wardarskiej - Skopja, Bitoli, Štipu (w sumie 7144 osób) oraz z Tracji (4 tys.) w marcu 1943 r. zostali przewiezieni do Skopja, do zorganizowanego na terenie miejscowej fabryki tytoniu obozu tymczasowego, skąd następnie zostali przetransportowani do obozu śmierci w Treblince, gdzie zginęli wszyscy (niektórzy zmarli z wyczerpania w drodze). Tylko nielicznym udało się uratować życie. Niektórzy ocaleli dzięki pomocy macedońskich sąsiadów lub uciekając do włoskiej strefy okupacyjnej, w której nie dokonywano internowań. Dla niewielkiej grupy młodych osób, niemających zobowiązań rodzinnych, częstokroć już od czasów przedwojennych sympatyzujących z ruchem komunistycznym, ratunkiem 
stał się czynny udział w wojnie. Wstępowały one w szeregi jugosłowiańskiej partyzantki, którą dowodził Josip Broz Tito, i walczyły przeciw okupacyjnym władzom bułgarskim oraz Niemcom, traktującym ich - ze względu na członkostwo w organizacji komunistycznej - jako wrogów politycznych. W tym kontekście warto zwrócić uwagę na pewien wątek wiążący w szczególny sposób jugosłowiańskich Żydów i Macedończyków. Jedno ze zdjęć eksponowanych w Centrum ukazuje Titę w towarzystwie bliskiego współpracownika i działacza komunistycznego pochodzenia żydowskiego, Moszy Pijadego, także w prezentowanym w ośrodku dokumentarnym filmie Lata robia swoje (2001) o roli Marszałka mówi się w kontekście wojennych losów Żydów z obszarów macedońskich jednoznacznie pozytywnie. Uznanie dla kontrowersyjnego z dzisiejszej perspektywy przywódcy Socjalistycznej Federacyjnej Republiki Jugosławii nie kłóci się z percepcją powojennego półwiecza pod rządami komunistów, które traktowane jest w Macedonii zasadniczo jako okres postępującej, dynamicznej emancypacji państwowej, ostatecznie zwieńczonej uzyskaniem niepodległości.

Z otwarciem Muzeum Holokaustu w Skopju wiąże się także pewne istotne przemilczenie, kładące się cieniem na i tak skomplikowane relacje macedońsko-bułgarskie oraz narusza zmitologizowaną wizję państwa bułgarskiego jako jedynego w Europie, któremu mimo przejściowego sympatyzowania z nazistami udało się ocalić własnych Żydów. I choć fakt ten został dowiedziony, rzadko wspomina się o cenie owego ocalenia. Otóż zorganizowana wystawa wprost mówi o bułgarskiej odpowiedzialności czy też współodpowiedzialności za zagładę macedońskich Żydów. Jak już wspominałam, tereny Macedonii Wardarskiej, należącej przed wojną do Królestwa Jugosławii, oraz Tracja Zachodnia i Macedonia Egejska w 1941 r., kiedy to Bułgaria podpisała z Niemcami pakt sojuszniczy, znajdowały się pod bułgarską jurysdykcją. Parlament zdominowany przez zwolenników orientacji proniemieckiej przyjął opracowaną przez ówczesnego ministra spraw wewnętrznych Petyra Garbowskiego ustawę, na mocy której dotkliwie ograniczono prawa obywatelskie ludności żydowskiej, a na obszarach zaanektowanych właściwie całkowicie je odebrano. Car Borys III z oporami podpisał dokument, tłumacząc swoją decyzję obawą, że gdyby Bułgarzy sami nie podjęli stosownych (rutynowych) kroków, Niemcy mogłyby narzucić bałkańskiemu sojusznikowi w tej kwiestii dużo bardziej restrykcyjne rozwiązania. W 1942 r. utworzono Komisariat do spraw żydowskich (Komisarstwo za ewrejskite woprosi), którego kierownictwo objął Aleksandyr Belew - jak podkreślają historycy, jeden z niewielu ideowych antysemitów bułgarskich ${ }^{3}$. Kiedy rok później Niemcy zaleciły Bułgarii wywiezienie Żydów do obozu koncentracyjnego, proponując za transport cenę 250 marek od osoby, władze w Sofii podjęły decyzję o deportacji osób pochodzących z ziem okupowanych. Rozstrzygająca okazała się tu kwestia obywatelstwa - otóż Żydzi z Macedonii i Tracji zostali pozbawieni statusu obywateli bułgarskich, a to pozwoliło „,jak najmniej dotkliwym kosztem” wypełnić sojusznicze zobowiązania. Między 22 a 29 marca 1943 r. ze

\footnotetext{
${ }^{3}$ Tadeusz Czekalski, Bułgaria, Warszawa: Trio, 2010, s. 175.
} 
stacji w Skopju wysyłano kolejne transporty. Już wkrótce ich celem ostatecznym miały stać się komory gazowe w Treblince.

Mówiąc o politycznych uwikłaniach problemu Żydów z Macedonii, należy wspomnieć o jeszcze jednym, sygnalizowanym już wcześniej aspekcie. Macedońskie państwo, zezwalając na budowę Centrum Pamięci o Zagładzie Żydów i współfinansując realizację projektu, występuje niejako w roli rzecznika macedońskich Żydów, dziś reprezentowanych przez niewielką, bo liczącą zaledwie 250 osób, wspólnotę. Tak gorliwa afirmacja tematu żydowskiego może być interpretowana jako szczególna odpowiedź na wewnętrzne problemy państwa z wielokulturowością, a w szczególności z obawami towarzyszącymi ekspansji nie tylko demograficznej, lecz także politycznej (często radykalnej) i gospodarczej Albańczyków (których liczba od początku lat dwutysięcznych znacznie wzrosła, głównie za sprawą napływu uchodźców z Kosowa oraz znacznych dysproporcji w przyroście naturalnym). W tej sytuacji Macedończycy, czujący się pomimo wszystko gospodarzami tych ziem i wciąż jeszcze stojący u sterów państwa, podejmują działania służące dowartościowaniu innych grup etnicznych, w tym również nielicznej, ale posiadającej ogromny potencjał kulturowy społeczności żydowskiej. Te zabiegi mają zatem sprzyjać rozbiciu konfliktogennego dwudzielnego porządku.

Skopijskie muzeum jest instytucją memorialno-edukacyjną, jest też pomnikiem i jest wreszcie miejscem, które w zamyśle twórców ma ustanawiać więź z przeszłością, a także budować poczucie wspólnoty międzykulturowej Macedończyków i Żydów, opartej na współbieżności doświadczenia historycznego. Na poziomie znaczeń konotowanych przez ekspozycję (nie są one wyrażone explicite) jest ona konstruowana przez ustanowienie analogii pomiędzy losem Żydów skazanych przez władze bułgarskie na zagładę i Macedończyków poddawanych bułgarskiej presji wynarodowienia. Zaprezentowana narracja muzealna stosunkowo niewiele mówi o wzajemnych relacjach między tymi grupami narodowymi (macedońską i żydowska), wykorzystuje natomiast - nośny zarówno w Macedonii, jak i szerzej na Bałkanach - kod dyskursu postkolonialnego, w którym obie zostają usytuowane w zależności od władzy, najpierw osmańskiej, w okresie wojennym bułgarskiej, a następnie komunistycznej. Na tym poziomie sugerowane jest więc podobieństwo między macedońskimi Żydami i Macedończykami, pozwala ono wywołać u odbiorcy Macedończyka oparte na mechanizmie identyfikacji zaangażowanie emocjonalne. W ten sposób także zostaje wyznaczony lokalny wymiar uniwersalnej pamięci o Zagładzie, uwikłany w znamienną dla tego obszaru sieć relacji międzywyznaniowych i międzyetnicznych. W tym kontekście na zorganizowanej w ośrodku 3 maja komemoracji, w której uczestniczyli ambasadorowie Niemiec i Polski symptomatyczną wymowę miały słowa Ljiljany Mizrahi, inicjatorki spotkania i przewodniczącej Zarządu Fundacji Zagłady Żydów z Macedonii, gdy z goryczą skonstatowała ona nieobecność na uroczystości przedstawiciela Ambasady Bułgarii.

Na wystawie w Centrum Pamięci o Zagładzie przeczytać można pewną opowieść-legendę o kluczach (znajdujących się obecnie w muzeum żydowskim w Sarajewie), które wygnańcy zabrali ze sobą z Hiszpanii na znak, że kiedyś wrócą do 
swych domów. W innej części ekspozycji zobaczyć można fotografię z 1960 r., która przedstawia Haima Sadikario i Samuela Mizrahi - ocalonych z Zagłady, którzy przyjechali wówczas do Polski po prochy swoich rodaków. Pod zdjęciem umieszczone zostały słowa: „Nigdy nie mówiliśmy naszym dzieciom o Holokauście, daliśmy im imiona tych, których straciliśmy w Treblince”. Dziś prochy Żydów z Macedonii (i Treblinki zarazem) zdeponowane są w skopijskim muzeum, które wszakże samo w sobie jest znakiem powrotu, wpisanego w dwutakt pamięci i zapomnienia. Przesłaniem owego symbolicznego powrotu wspólnoty żydowskiej do skopijskiej Čivutany jest - posłużmy się słowami Marca Augé - „odzyskanie straconej przeszłości”, „odnalezienie ciągłości istnienia”, ale także otwarcie na przyszłość4

${ }^{4}$ Zob. Marc Augé, Formy zapomnienia, tłum. Anna Turczyn, Kraków: Universitas, 2009. 